\title{
The Effectiveness of Peer-Led Technology on HIV Prevention among Adolescent in Bandung
}

\author{
Linlin Lindayani $^{1^{*}}$, Heni Purnama ${ }^{2}$, Irma Darmawati ${ }^{3}$, Vita Lucya ${ }^{4}$ \\ ${ }^{1,2,3,4}$ Sekolah Tinggi Ilmu Keperawatan PPNI Jawa Barat, Indonesia \\ *Corresponding email: linlinlindayani@gmail.com
}

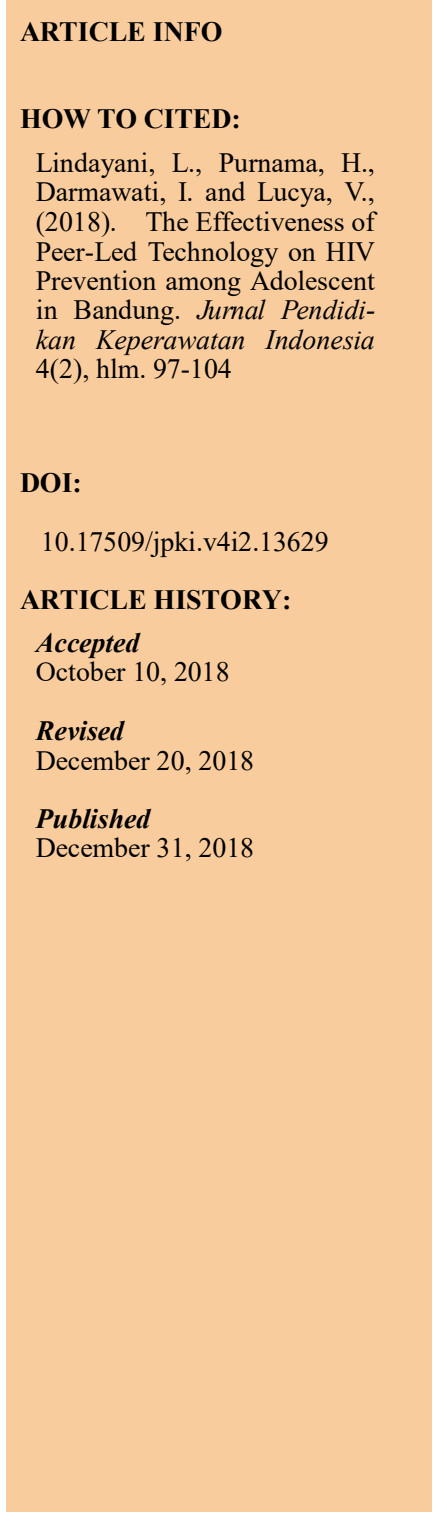

\section{A B S T R A C T}

The prevalence of HIV infection in aged 15-19 years old was increased significantly every year. Adolescent is a high-risk groups for HIV infection due to high chance to try something new and having big influenced by their peer in school. There is limited intervention utilizing technology conducted in Indonesia to reduce the risk of HIV among adolescents. This study aimed to test the effectiveness of peerled technology on knowledge and attitude towards HIV prevention among adolescent in Bandung. This research was a queasy experiment with one group conducted in a one of private senior high school in Indonesia from April to August 2018. The sample in this study was a student in one of private high school in Bandung. The inclusion criteria in this study were high school students in grade 1,2; three sample technique used simple random sampling. The Bahasa version of knowledge and attitude towards HIV prevention were used to measure the outcome. Paired t test used to test the mean sore of knowledge and attitude the intervention before and after. A total of 28 senior high school students agreed to join in this study. This study found that peerled technology was useful to improve the knowledge and attitudes of high school students towards HIV prevention, mainly through sexual transmission ( $\mathrm{p}$-value $<0.001$, with a mean difference between pre-test and post-test, was 5.2 for knowledge and 3.19 for attitude). In conclusion, utilizing technology to provide health education in adolescent effectively to improve knowledge and attitude towards HIV prevention.

Kata kunci: HIV, prevention, knowledge, attitude, peer-led, technology

\section{$A B S T R A K$}

Prevalensi HIV infeksi pada umur 15-19 tahun meningkat secara signifikan setiap tahun. Remaja adalah kelompok berisiko tinggi untuk infeksi HIV, pada masa ini mereka senang mencoba sesuatu yang baru dan juga faktor tingginya pengaruh teman sebaya di sekolah. Masih sedikit intervensi pencegahan HIV yang memanfaatkan teknologi untuk 
Lindayani, L., Purnama, H., Darmawati, I. \& Lucya, V.| The Effectiveness of Peer-Led Technology on HIV Prevention...

untuk mengurangi risiko HIV kalangan remaja di Indonesia. Penelitian ini bertujuan untuk menguji efektivitas peer lead teknologi terhadap pengetahuan dan sikap dalam pencegahan HIV di antara remaja di Bandung. Penelitian ini merupakan kuasi eksperimen pada satu kelompok perlakuan yang dilakukan di salah satu SMA swasta di Indonesia dari bulan April hingga Agustus 2018. Kriteria inklusi dalam studi ini adalah siswa SMA kelas 1 dan 2. Teknik pengambilan sample dengan menggunakan simple random sampling. Instrumen versi bahasa indonesia digunakan sebagai instrumen untuk mengukur pengetahuan dan sikap terhadap pencegahan HIV. Analisa data menggunakan paired T test untuk mebandingkan hasil sebelum dan sesudah intervensi. Total sejumlah 28 siswa SMA setuju untuk bergabung dalam studi ini. Studi ini menemukan bahwa peer lead technology berguna untuk meningkatkan pengetahuan dan sikap siswa SMA terhadap pencegahan HIV, terutama melalui transmisi seksual (p-nilai $<0.001$, dengan perbedaan yang berarti antara sebelum dan sesudah intervensi adalah 5.2 untuk pengetahuan dan 3.19 untuk sikap). Kesimpulannya, pemanfaatan teknologi dalam pendidikan kesehatan pada remaja terbukti efektif dalam meningkatkan pengetahuan dan sikap terhadap pencegahan HIV.

Kata kunci: HIV, pencegahan, pengetahuan, sikap, peer-lead, teknologi

\section{INTRODUCTION}

There is increasing the number of new human immunodeficiency virus (HIV)-infection among adolescent in Indonesia. The prevalence of HIV infection in aged 15-19 years old was increased from $3.2 \%$ in 2012 to $3.7 \%$ in 2016 (Ministry of Health RI, 2017). Although aged 20 to 49 reported as the highest prevalence of HIV infection, there was study found that the incubation period for HIV ranged from 5 to 10 years. Thus they may be infected in aged 10 to 15 years old (Ministry of Health RI, 2017). In 2017, there were 5,714 of people aged 15-19 years old being infected by HIV and 2,208 diagnosed with acquired immunodeficiency syndrome (AIDS) (Ministry of Health RI, 2017). Bandung is one of a big city in Indonesia that reported having a higher prevalence of HIV infection. It's estimated that about 1.272 students in junior and senior high school infected by HIV by sexual transmission and injecting drugs use (Department of Health West Java, 2017).

According to the psychological, developmental stage, adolescents is recognized as a stage of finding and building characters or identity also a transition period from child to adult (Yusuf, LN, 2015). Therefore, they tend to be at high-risk groups for HIV infection due to high chance to try something new and having big influenced by their peer in school. The previous study reported that about $90 \%$ of an adolescent in Bandung had sexual activity before marriage (Tempo.co, 2017). The Bandung City Health Office (2017) reported that $30 \%$ of adolescent visits to health centers were related to premarital sex consultation, unwanted pregnancy, sexually transmitted diseases, and HIV and AIDS. At this time they have begun to try to be sexually active and have a high curiosity about drug abuse so that it becomes an age group that is very vulnerable to HIV transmission.

The HIV prevention in adolescents focused on the application of ABCD (abstinent, be faithful, condom, and Drugs) principles, but until now there is no clear protocol for implementation and still put an adolescent at high risk of HIV infection (HIV/AIDS commission, 2002). Prevention which focuses on harm reduction for injecting drug users showed good results because the transmission through drug needles is reduced dramatically. However, prevention of HIV transmission through sexual transmission more focuses on condom use. However, the method of using condoms has become controversial in Indonesia due to religious issues. So, the implementation is less effective and not accepted in the Indonesian community. One study reported that condom use in Indonesia at a highrisk group of HIV infection only reached $25.4 \%$, although condoms could be sold freely in stores (Wanda, 2015). Therefore, effective approach for HIV prevention among adolescent is needed. 
Indonesia ranked as the 6th largest number of internet and social media users country within the world (kominfo.org.id). The use of technology through social media applications has become very important in HIV prevention. Adolescents reported as the most internet and social media user compared to other age groups. Until now, no intervention integrates information and social media technology in HIV prevention conducted in adolescents, especially in Indonesia. The results of previous studies in Senegal showed that integration of technology in HIV prevention among adolescents was effective in reducing risk behavior and new cases of HIV (Massy, 2013). This approach is pressurized to be effective as a health education media and reminder for adolescents to stay away from risky behavior towards HIV transmission. Therefore, this study aimed to test the effectiveness of peerled technology on knowledge and attitude towards HIV prevention among adolescent in Bandung.

\section{METHOD}

\section{Study design}

This research is a queasy experiment with one group aimed to measure the effectiveness of peer-lead technology as a new approach in HIV prevention among adolescents. This study was conducted in a one of private senior high school in Indonesia from April to August 2018.
Students will be randomized to be included in the intervention using computer software.

\section{Intervention}

Peer-lead technology is a school-based program that aims to improve the competence of students towards HIV prevention related to sexual behavior with the use of information technology as a medium for information delivery. This program was developed based on the social learning theory (Bandura, 1977) and The InformationMotivation-Behavioral Skills Model (IBM) (Fisher, 1992). The peer-lead technology program was also developed based on the principle of capacity building empowerment, where in addition to being formed peer educators also expanded community-based partnerships in collaboration between schools and health education institutions and communities around the school environment as a social control for program sustainability. This program contains structured content with clear protocols to be implemented. The intervention consists of five modules: 1) Information and cognitive restructuring, 2) Social skills training; 3) Training problem solving; 4) Maintenance strategies: self-management; 5) Covert behavior rehearsal. All the information provided in the website that contains an interactive discussion with students so that every time they have problems they can share and get responses from other in advance.

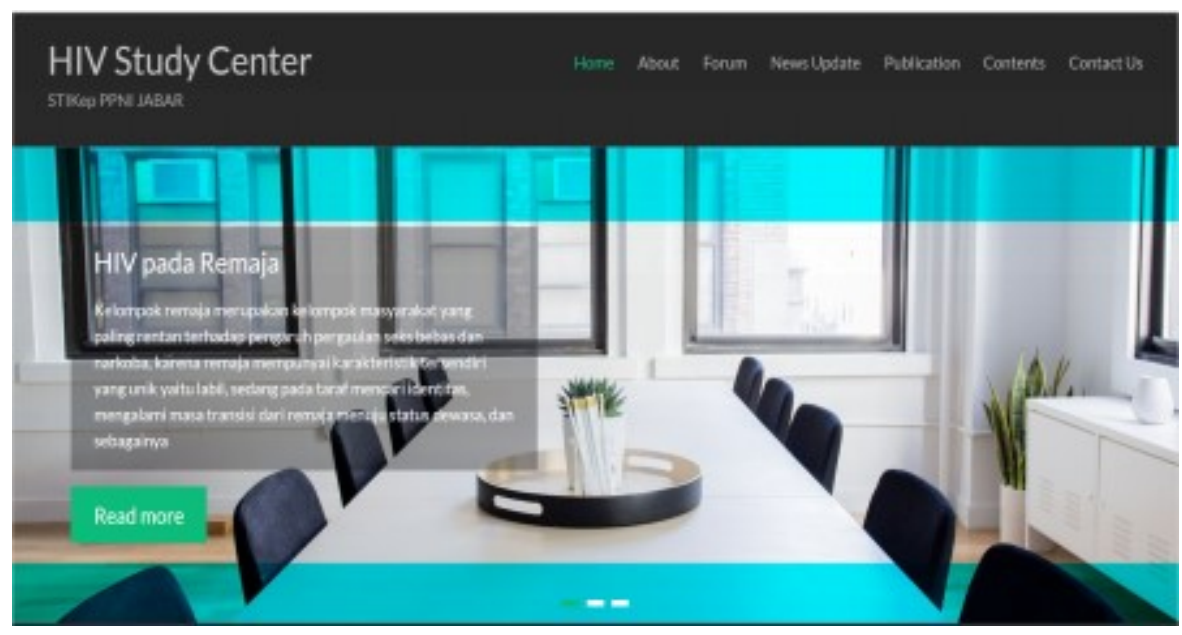

Figure 1. Website design 


\section{Sample}

The sample in this study was a student in one of private high school in Bandung. The inclusion criteria in this study were high school students in grade 1, 2; three sample technique used simple random sampling. The sample size is calculated using G-Power Software Version 3.1.6 assuming t-test, $\alpha=0.05$, effect size $=0.25$ (Cohen, 1992), power level $=0.80,2$ times measurement. So that the total sample recruited is 28 students for each group.

\section{Measurement}

The demographic characteristics were collected including age, gender, religion, ethnic, and grade. Access to information also has been collected included ever exposed to sexual education previously, sources of information, the used and frequency of internet and social media. The knowledge and attitude towards HIV prevention were measure using the Bahasa version that initially developed by Uraget (2013).

Knowledge of HIV prevention consists of 17 questions which include: 10 questions about how to transmit HIV and seven questions about misconceptions about HIV transmission and prevention. The answer choices comprised of answers yes and no and don't know or refuse. Each correct answer is given a score of 1 and if you do not know and wrong is given a score of 0 . The total score will be categorized as having sufficient knowledge if the score is more than 16 and do not have enough knowledge of the score of less than 15 . The reliability of this instrument is quite good that is equal to 0.73 (Urgate, 2013). In the Bahasa version, the Cronbach' Alpha was 0.72 (Purnama, 2018).

\section{Data analysis}

Descriptive and inferential analysis statistics was used to explain demographic data and critical variables. Pair-t tests wlused for evaluating the effectiveness of the intervention. The 5\% significance level used to determine the differences in the critical variable score before and after the intervention.

\section{RESULT}

A total of 28 senior high school students agreed to join in this study. The most of students (72.7\%) were women with an average age of $16.16(\mathrm{SD}=0.88) \quad($ Table 1$)$. Information sources that often used by students were social media (96.4\%). Some students $(92.9 \%)$ have received education about sexual health.

\section{Knowledge towards HIV prevention}

The majority of respondent ever hear about HIV (99.4\%) and aware about the negative impact of being infected by HIV in the future (98.2). However, they were lack of knowledge or misunderstanding about the use of condom for HIV prevention and vaccine for prevention of cervical cancer.

\section{Attitude towards HIV prevention}

The majority of students agree that Health education about sexuality is very important for adolescents (93.9\%) and having sex must be after marriage (91.5). The respondent reported negative attitude towards communication about sexual health with their boyfriend and virginity is not essential.

\section{The effectiveness of peer-led technology on knowledge and attitude towards HIV preven- tion}

Based on the results of paired t-test it was found that peer-led technology was useful to improve the knowledge and attitudes of high school students towards HIV prevention, mainly through sexual transmission ( $p$-value $<0.001$, with a mean difference between pre-test and post -test, was 5.2 for knowledge and 3.19 for attitude) (Table 4). The average score of knowledge after the intervention was $19.9(\mathrm{SD}=3.21)$ and attitude was $31.2(\mathrm{SD}=1.34)$. 
Lindayani, L., Purnama, H., Darmawati, I. \& Lucya, V.| The Effectiveness of Peer-Led Technology on HIV Prevention...

Table 1. Baseline characteristics of senior high school in one of private school, Bandung (n=28)

\begin{tabular}{lc}
\hline \multicolumn{1}{c}{ Characteristics } & n (\%) \\
\hline $\begin{array}{l}\text { Age (mean } \pm \text { SD) } \\
\text { Gender }\end{array}$ & $16.16 \pm 0.88$ \\
Women & $20(71.4)$ \\
Men & $8(28.6)$ \\
Religion & $26(92.8)$ \\
Islam & $1(3.6)$ \\
Catholic & $1(3.6)$ \\
Protestant & $18(64.3)$ \\
Ethnic $\quad$ Sundanese & $2(7.1)$ \\
$\quad$ Minang & $8(28.6)$ \\
Javanese & $10(35.7)$ \\
I & $10(35.7)$ \\
II & $8(28.6)$ \\
III & $26(92.9)$ \\
Ever exposed to sexual health education previously & $27(96.4)$ \\
Social media used & \\
The frequency of using social media & $0(0)$ \\
Once a month & $1(3.6)$ \\
Twice a week & $2(7.1)$ \\
Three times a week & $25(89.3)$ \\
Every day &
\end{tabular}

Table 2. The distribution of each item of HIV prevention-related knowledge before intervention among adolescent in one of private senior high school, Bandung $(\mathbf{n}=\mathbf{2 8})$

\begin{tabular}{lc}
\hline \multicolumn{1}{c}{ Questions } & \% yes \\
\hline Have you ever heard about HIV? & 99.4 \\
Are you aware of the dangers of HIV? & 98.2 \\
$\begin{array}{l}\text { Are you aware that free sexual intercourse and the use of drug syringes can trans- } \\
\text { mit HIV alternately? }\end{array}$ & 95.2 \\
Have you ever heard of a sexually transmitted disease? Like the lion king, human & 70.9 \\
papillomavirus (HPV)? & 70.3 \\
Did you know that HPV can cause cervical cancer in women? & 50.3 \\
Do you know that there is a vaccine for prevention of cervical cancer? & 44.8 \\
\hline
\end{tabular}




\section{DISCUSSION}

This study found that peer-led technology was effective to improve knowledge and attitude towards HIV prevention among adolescent in Indonesia. It was consistent with the previous research conducted in Sinegal found that developing peer education by utilizing technology effective reduced the risk of HIV infection in Adolescent, particularly on increasing the awareness of HIV infection (Massy, 2013). However, there was a limitation found in the previous study. First, the intervention was set up no involved the surrounding community or also collaboration with health education institutions for the continuity of the program so that the continuity of the program does not exist. Second, previous research was based on the concept of a theory that indeed is different from the conditions of adolescents in Indonesia. Thus, our current study might be more recommended to be implemented or adapted in Indonesia. Considering the higher percentage of social media users in the young group of age, future study integrating web-based program and social-media will provide robust results.

This study also found that more than half of adolescent having a lack of knowledge or misunderstanding about the use of condom for HIV prevention. The use of the condom was recommended by the world health organization (WHO) as one method for prevention of HIV and other sexually transmitted infection, however, in Indonesia condom campaign is contro-

Table 3. The distribution of each item of HIV prevention-related attitude before intervention among adolescent in one of private senior high school, Bandung $(n=28)$

\begin{tabular}{lc}
\hline \multicolumn{1}{c}{ Questions } & \% agreed \\
\hline Masturbate danger for health & 47.3 \\
Health education about sexuality is very important for adolescents & 93.9 \\
Having sex after marriage & 91.5 \\
Marry someone who is not "virgin" for both men and women & 10.3 \\
Isolate patients with sexually transmitted diseases to keep everyone safe & 56.4 \\
Cover prostitution to control the transmission of sexually transmitted dis- & 77.6 \\
eases & 29.7 \\
HIV can be cured & 63.6 \\
Do you want to do an HIV test at the hospital voluntarily & 22.4 \\
I am sure that I can discuss with your boyfriend about sexual health & 90.9 \\
I am sure I can refuse not to have sex before marriage & \\
\hline
\end{tabular}

Table 4. The effectiveness of peer-led technology on knowledge and attitude towards HIV prevention among adolescent $(n=28)$

\begin{tabular}{lllll}
\hline & Pre-test & Post-test & $p$-values & Mean different \\
& Mean (SD) & Mean (SD) & & \\
\hline Knowledge & $11.8(1.95)$ & $19.9(3.21)$ & 0.001 & 5.2 \\
Attitude & $29.7(2.62)$ & $31.2(1.34)$ & 0.001 & 3.19 \\
\hline
\end{tabular}


versial. Although many mini markets are selling the condom freely, stigma to the condom user exists. That might be one of the reasons for having others opinion about the condom. Furthermore, the majority of adolescent did not know other sexually transmitted infection that closely associated with HIV like human papillomavirus as important etiology for cervical cancer.

Surprisingly, our respondent reported that virginity is not an important issue before marriage. The transition of this principle may due to the modernization issues and increasing the accessibility to the information widely. However, in Indonesia culture where the majority of them is Islam, this issues may be can be a primary data to be considered for future intervention. However, after the intervention was conducted may of the re-changing their viewpoint again about virginity. A meta-analysis that reports that peer educator proved to be more effective in reducing sexual behavior at risk among adolescents and required cheaper compared to involving health workers (Kim, 2008; Medley, 2009; Simoni, 2011; Arnol, 2012).

\section{REFERENCES}

Bandura. (1997). A Self-efficacy: Toward a unifying theory of behavioral change. Psychol Rev; 84: $191-215$.

Fisher J D, Fisher W A. (1992). Changing AIDS -risk behavior. Psychol Bull; 111: 455 - 74

Kementrian Kesehatan RI. (2016). Profil Kesehatan Indonesia tahun 2015. Jakarta : Kementrian Kesehatan RI.

Kim C R, Free C. (2008). Recent evaluations of the peer-led approach in adolescent sexual health education: A systematic review. Perspect Sex Reprod Health; 40: 144 - 51.

Massye, P. (2013). School-based HIV prevention in Dakar, Senegal: Findings from a peer-led program. Int'l. Quarterly of Community Health Education, Vol. 33(2) 129141.
Although some researchers have previously used peer educators, the material used is not structured and only increases knowledge, does not focus on improving skills so that the application still puts someone at high risk of contracting HIV. Subsequent research focuses on developing peer educators with the use of technology needed for the continuity of the program. In conclusion, utilizing technology to provide health education in adolescent effectively to improve knowledge and attitude toward HIV prevention.

\section{Conclusion}

Peer-led technology was useful to improve the knowledge and attitudes of high school students towards HIV prevention. This program effectively to improve knowledge focusing in how to transmit HIV and knowledge about misconceptions in HIV transmission and prevention.

Medley A, Kennedy C, O’ Reilly K, Sweat M. (2009) Effectiveness of peer education interventions for HIV prevention in developing countries: A systematic review and Meta analysis. AIDS Educ Prev; 21: 181 - 206.

Morales. (2014). the short-term impact of peers as co-facilitators of an HIV prevention programme for adolescents: A cluster randomised controlled trial. The European Journal of Contraception and Reproductive Health Care, 2014; 19: 379-391.

Simoni JM, Nelson KM, Franks JC, et al. (2011) Are peer interventions for HIV effi cacious? A systematic review. AIDS Behav; 15: 1589 - 95. 
Purnama, H. Darmawati, Irma, Lindayani,L. (2018). The Effectiveness of Skills for Adolescents with Healthy Sexuality (SAHS) Program on Reducing the Risk of HIV Transmission among Adolescents. INJECT.Oct.2018

Tempo.conasional. (2015, Desember 31). Retrieved from tempo.cobandung: http:// nasional.tempo.co/read/

news/2015/12/31/058732095/ratusan-remaja -bandung-lakukan-hubungan-seks-berisiko

Tolli M. (2012). Effectiveness of peer education interventions for HIV prevention, adolescent pregnancy prevention and sexual health promotion for young people: A systematic review of European studies. Health Educ Res; $27: 904-13$.

Ugarte. (2013). Assessing knowledge, attitudes, and behaviors related to HIV and AIDS in Nicaragua: A community-level perspective. Sexual \& Reproductive Healthcare: 4 (2013) $37-44$
UNAIDS. (2016). Global Report: UNAIDS report on the global AIDS epidemic. Retrieved from:http://www.unaids.org/sites/default/files/ media_asset/ UNAIDS_Global_Report_2016_en_1. pdf . Diakses pada 10 Juli 2016.

Yusuf, LN, S. (2015). Psikologi Perkembangan Anak dan Remaja. Bandung: PT Remaja Rosdakarya.

Wanda. (2015). Presentase pemakaian kondom pada transaksi seksual terakhir pada WPS di Saritem Bandung. Prosiding pendidikan dokter. ISSN 2460-657X.

Wang. (2014). Do community-based strategies reduce HIV risk among people who inject drugs in China? A quasi-experimental study in Yunnan and Guangxi provinces. Harm Reduction Journal , 11:15 